\section{Correspondence on 'Novel ultrasonographic Halo Score for giant cell arteritis: assessment of diagnostic accuracy and association with ocular ischaemia'}

We read with great interest the study of van der Geest et $a l^{1}{ }^{1}$ in which a novel ultrasound (US) score was used for the quantification of vascular inflammation in patients with suspected giant cell arteritis (GCA). Halo Score exhibited a moderate diagnostic accuracy for GCA, but was associated with systemic inflammation and risk for visual loss. Comparable results were shown for Halo Count, which is the sum of arterial segments with a Halo sign, as estimated by bilateral US examination of four arterial sites.

GCA is a type of large-vessel vasculitis that affects mainly elderly people. Due to the devastating complications of GCA, early diagnosis is of paramount importance. US of temporal and axillary arteries exhibits high sensitivity and specificity in GCA diagnosis and has been introduced as the first-line imaging modality in suspected GCA. ${ }^{2}$ Fast-track GCA clinics have been organised and adopted US as the cornerstone of GCA diagnosis. ${ }^{3}$ However, it is still debatable which arteries should be scanned in the initial US assessment of a patient with suspected GCA. Facial artery is one of the less studied arteries in these patients. We aimed to investigate the utility of facial artery US in the evaluation of patients with possible diagnosis of GCA.

We prospectively included patients that were referred to our clinic for suspected GCA during the period from July 2017 to February 2020. All patients were over 50 years and had increased inflammation markers (erythrocyte sedimentation rate $(\mathrm{ESR}) \geq 50 \mathrm{~mm} /$ hour and $\mathrm{C}$ reactive protein $(\mathrm{CRP}) \geq 10$ $\mathrm{mg} / \mathrm{L}){ }^{45}$ Patients with active infection and malignancy were excluded. Demographic (age, gender) and clinical (new-onset headache, ischaemic symptoms: jaw claudication, scalp tenderness and visual disturbances, polymyalgia rheumatica symptoms, fever) characteristics were recorded. Both temporal arteries were examined for abnormalities (tenderness, swelling, decreased pulse). Superficial common temporal arteries and their branches, facial and axillary arteries were bilaterally evaluated at their full length by colour Doppler ultrasonography. A General Electric Healthcare LOGIQ-E9 machine and a broad spectrum linear transducer were used. US methodology followed was according to the current guidelines ${ }^{2}{ }^{6}$; the parameters used in temporal arteries examination were also applied in facial arteries. Halo Count was retrospectively calculated, as previously described by van der Geest et al. ${ }^{1}$ All patients provided written informed consent.

Fifty-three patients were included; $73.6 \%$ were females, with a mean $\pm S D$ age of $71.1 \pm 10.2$ years. Fifteen patients had an US suggestive of vasculitis (table 1); temporal arteries' US was positive in 11 patients, while in another four patients axillary artery US was suggestive of large-vessel GCA. Importantly, US of facial arteries was positive in four patients, all of which had also a positive temporal US. No patient with positive temporal or facial artery US had a positive axillary US and vice versa. In all patients with positive US, clinical diagnosis of GCA was confirmed after a 6-month follow-up. After applying univariate analysis, scalp tenderness, visual manifestations, temporal artery abnormalities in physical examination and thrombocytosis were associated with positive findings in facial artery US (table 1). Halo Count did not differ between those with positive both temporal and
Table 1 Results from US examinations performed and univariate analysis of clinical manifestations and associations with facial artery US findings

\begin{tabular}{|c|c|c|c|}
\hline & Positive US & & \\
\hline Temporal artery, $\mathrm{n}(\%)$ & $11 / 53(20.8)$ & & \\
\hline Facial artery, n (\%) & $4 / 46(8.7)$ & & \\
\hline \multirow[t]{2}{*}{ Axillary artery, $\mathrm{n}(\%)$} & $4 / 46(8.7)$ & & \\
\hline & Facial US & & \\
\hline Symptoms & $\begin{array}{l}\text { Positive } \\
(n=4)\end{array}$ & $\begin{array}{l}\text { Negative } \\
(n=42)\end{array}$ & $P$ value \\
\hline Age (years)* & $72.0 \pm 7.6$ & $71.4 \pm 10.7$ & 0.459 \\
\hline Female sex, $\mathrm{n}$ & 3 & 30 & 1.000 \\
\hline Headache, $n$ & 3 & 11 & 0.078 \\
\hline Jaw claudication, $\mathrm{n}$ & 2 & 7 & 0.167 \\
\hline Scalp tenderness, $\mathrm{n}$ & 3 & 3 & 0.005 \\
\hline Visual symptoms, $\mathrm{n}$ & 2 & 1 & 0.017 \\
\hline PMR, n & 3 & 18 & 0.318 \\
\hline Fever, $\mathrm{n}$ & 3 & 11 & 0.078 \\
\hline Temporal artery abnormalities, $\mathrm{n}$ & 3 & 8 & 0.025 \\
\hline Thrombocytosis, n & 3 & 5 & 0.020 \\
\hline
\end{tabular}

Significant values are presented with bold fonts.

${ }^{*}$ Age is presented as mean $\pm \mathrm{SD}$.

PMR, polymyalgia rheumatica; US, ultrasound.

facial artery and those with vasculitis solely in temporal artery (5.5 (4.25-6) vs 5 (4-6), p=0.490).

US of facial artery has been proposed to be included in the evaluation of patients with suspected GCA. ${ }^{78}$ We demonstrated that $36.3 \%$ of patients with temporal arteritis might also have facial arteritis. Other researchers had reported vasculitis of facial arteries in $12 \%-41 \%$ of GCA patients. ${ }^{910}$ Despite the substantial frequency, the diagnostic yield of facial artery US in GCA is questionable. We showed that inflammation in facial artery was not associated with the extent of vascular inflammation in temporal and axillary arteries, as illustrated by the Halo Count. As Halo Count correlates well with CRP and platelets count, ${ }^{1}$ GCA patients with affected facial artery might not have an increased inflammation burden compared with those without. Moreover, the presence of ischaemic symptoms (scalp tenderness and visual symptoms), temporal artery abnormalities and thrombocytosis was associated with increased possibility of facial arteritis. Ješe et al have reported that GCA patients with insulted facial arteries have more often jaw claudication and visual disturbances. ${ }^{9}$ In contrast to the aforementioned study, we did not find positive facial artery US in patients with normal temporal arteries.

In the context of a fast-track GCA clinic every additional artery evaluated is time-consuming and patient-disturbing. US of facial arteries might not be necessary for the initial evaluation of patients with suspected GCA, especially if ischaemic symptoms, pathological signs in temporal arteries and thrombocytosis are absent. As the population of this study is not large enough to lead to firm conclusions, prospective studies from larger cohorts will define if facial arteries' US has any additive value in the diagnosis of GCA.

Gerasimos Evangelatos $\odot$, 1,2 George E Fragoulis $\odot$, ${ }^{1,2}$ Alexios Iliopoulos ${ }^{2}$ ${ }^{1}$ Rheumatology Unit, First Department of Propaedeutic Internal Medicine, National and Kapodistrian University of Athens, Athens, Attica, Greece

${ }^{2}$ Rheumatology Department, 417 Army Share Fund Hospital (NIMTS), Athens, Greece

Correspondence to Dr Gerasimos Evangelatos, Rheumatology Unit, First

Department of Propaedeutic Internal Medicine, National and Kapodistrian University of Athens, Athens, Attica, Greece; gerevag@gmail.com 
Twitter George E Fragoulis @FragoulisGeorge

Contributors GE: study design, data collection, analysis and interpretation. Drafted the manuscript. GF: drafted and critically revised the manuscript. Al: critically revised the manuscript. All authors approved the final version of the manuscript.

Funding The authors have not declared a specific grant for this research from any funding agency in the public, commercial or not-for-profit sectors.

Competing interests None declared.

Patient and public involvement Patients and/or the public were not involved in the design, or conduct, or reporting, or dissemination plans of this research.

Patient consent for publication Not required.

Provenance and peer review Not commissioned; internally peer reviewed.

(C) Author(s) (or their employer(s)) 2020. No commercial re-use. See rights and permissions. Published by BMJ.

\section{D) Check for updates}

To cite Evangelatos G, Fragoulis GE, lliopoulos A. Ann Rheum Dis Epub ahead of print: [please include Day Month Year]. doi:10.1136/annrheumdis-2020-219463

Received 6 November 2020

Accepted 7 November 2020

\section{CSLinked}

http://dx.doi.org/10.1136/annrheumdis-2020-219477

Ann Rheum Dis 2020;0:1-2. doi:10.1136/annrheumdis-2020-219463
ORCID iDs

Gerasimos Evangelatos http://orcid.org/0000-0003-3822-3093

George E Fragoulis http://orcid.org/0000-0003-4932-7023

\section{REFERENCES}

1 van der Geest KSM, Borg F, Kayani A, et al. Novel ultrasonographic halo score for giant cell arteritis: assessment of diagnostic accuracy and association with ocular ischaemia. Ann Rheum Dis 2020;79:393-9.

2 Dejaco $C$, Ramiro S, Duftner $C$, et al. EULAR recommendations for the use of imaging in large vessel vasculitis in clinical practice. Ann Rheum Dis 2018;77:636-43.

3 Diamantopoulos AP, Haugeberg G, Lindland A, et al. The fast-track ultrasound clinic for early diagnosis of giant cell arteritis significantly reduces permanent visual impairment: towards a more effective strategy to improve clinical outcome in giant cell arteritis? Rheumatology 2016;55:66-70.

4 Dejaco C, Duftner C, Buttgereit F, et al. The spectrum of giant cell arteritis and polymyalgia rheumatica: revisiting the concept of the disease. Rheumatology 2017:56:506-15.

5 Hunder GG, Bloch DA, Michel BA, et al. The American College of rheumatology 1990 criteria for the classification of giant cell arteritis. Arthritis Rheum 1990;33:1122-8.

6 Chrysidis S, Duftner C, Dejaco C, et al. Definitions and reliability assessment of elementary ultrasound lesions in giant cell arteritis: a study from the OMERACT large vessel vasculitis ultrasound Working group. RMD Open 2018;4:e000598.

7 Schmidt WA. Ultrasound in the diagnosis and management of giant cell arteritis. Rheumatology 2018;57:ii22-31.

8 Schäfer VS, Juche A, Ramiro S, et al. Ultrasound cut-off values for intima-media thickness of temporal, facial and axillary arteries in giant cell arteritis. Rheumatology 2017:56:1479-83.

9 Ješe R, Rotar Žiga, Tomšič M, et al. The role of colour Doppler ultrasonography of facial and occipital arteries in patients with giant cell arteritis: a prospective study. Eur J Radiol 2017;95:9-12.

10 Schmidt WA, Natusch A, Möller DE, et al. Involvement of peripheral arteries in giant cell arteritis: a color Doppler sonography study. Clin Exp Rheumatol 2002;20:309-18. 